\title{
FOR A RELATIONAL CRITICAL DISCOURSE ANALYSIS
}

Tomasz Zarycki

University of Warsaw

\section{/// Four Discourse Analyses}

This paper provides a relational sociological perspective on contemporary linguistics, with particular emphasis on discourse analysis and socalled "Critical Discourse Analysis" (CDA). In other words, it is an attempt to expose what are considered to be serious limitations of the critical approach in discourse analysis. As it will be argued, critical discourse analysis, which has also become a popular approach in sociological studies, can be seen as largely involved in a non-reflexive naturalization and reproduction of the power relations underlying dominant discourses, in spite of its declared ambition to be involved in their deconstruction. This could also be said about most other schools of discourse analysis and probably about most branches of linguistics. However, this text will focus particularly on $\mathrm{CDA}$ and its forms of involvement in the reproduction of social relations, because the case of CDA seems to offer the most striking example of discourse analysis' inability to challenge its own premises despite its clearly expressed intentions to tackle the problem of power relations in which all social actions are involved.

In order to expose the paradoxical role of CDA, I would like to draw on Michael Burawoy's typology of schools of sociology (Burawoy 2005). Let me remind the reader that Burawoy has proposed that we distinguish four types of sociology: professional sociology, public sociology, policy sociology, and critical sociology. His two criteria of this "division of sociological labor" were based on the questions of "for whom" and "for what" sociology is pursued. These two questions defined two dimensions of his typology. The first distinguishes sociology for an academic audience ("pro- 
fessional" and "critical" sociologies) from sociology for a non-academic audience ("policy" and "public" sociologies). The second dimension is based on the opposition between the production of instrumental knowledge ("professional" and "policy" sociologies) and production of reflexive knowledge ("public" and "critical" sociologies). Policy sociology, as Burawoy argued, "is sociology in the service of a goal defined by a client. Policy sociology's raison d'être is to provide solutions to problems that are presented to us, or to legitimate solutions that have already been reached" (Burawoy 2005: 9). "Public sociology, by contrast, strikes up a dialogic relation between the sociologist and the public in which the agenda of each is brought to the table and each adjusts to the other. In public sociology, discussion often involves values or goals that are not automatically shared by both sides" (Burawoy 2005: 9). Professional sociology supplies "true and tested methods, accumulated bodies of knowledge, orienting questions, and conceptual frameworks," while critical sociology "examines the foundations-both the explicit and the implicit, both normative and descriptive-of the research programmes of professional sociology" (Burawoy 2005: 10). Burawoy's scheme can be easily applied to contemporary discourse analysis. Thus, first, we have "professional discourse analysis" dealing with the systematic study and description of discourse types and their uses. Second, we have "policy discourse analysis," which is best represented by branches dedicated to language and discourse standardization, education, or language testing. What is currently known as "critical linguistics," in particular under the rubric of CDA, can be considered an equivalent to "public sociology" rather than "critical sociology." This may be because of its overt political commitment to addressing issues defined in terms of broader social or political problems. In other words, CDA openly presents itself as involved in the solution of social issues: addressing, to a large extent, non-academic audiences. As Teun van Dijk argued, for example, CDA is "a type of discourse analytical research that primarily studies the way social power abuse, dominance, and inequality are enacted, reproduced, and resisted by text and talk in the social and political context. With such dissident research, critical discourse analysts take explicit position, and thus want to understand, expose, and ultimately resist social inequality" (van Dijk 2001: 352). Theo van Leeuwen, in turn, has defined CDA's goal as the critique of the hegemonic discourses and genres that effect in inequalities, injustices, and oppression in contemporary society (van Leeuwen 2009).

The last category from the above-proposed two-dimensional typology of "division of discourse analysis' labor" would be critical discourse analy- 
sis defined along the lines of Burawoy's understanding of critical sociology. As I argue in this text, however, such an approach does not yet exist as a coherent school of discourse analysis, although several attempts at developing such a mode of reflection have already been made, in particular within the discipline of linguistic anthropology (e.g., Bucholtz 2001, Slembrouck 2001) or communication studies (e.g., Jones 2007). This paper is an effort to propose some of the possible ways this school of thought could develop, relying primarily on sociological inspiration. I am tentatively calling the proposed model a relational critical discourse analysis. Thus this will be a discipline focused on analysing the foundations of discourse analysis and its social functions, with its embeddedness in relations of power, while critically oriented towards its own field rather than the external social world. Defined in this way, such a field could be seen as a "discourse analysis of discourse analysis" to allude to Bourdieu's call for the development of a "sociology of sociology" (Bourdieu \& Wacquant 1992). It could also be imagined as a critical sociology of discourse analysis. The proposed approach, as will be suggested in more detail below, would combine the tools and frameworks of both critical sociology and CDA to focus on the discourse of discourse analysis itself.

\section{/// Relational Critical Discourse Analysis as a Contextual Approach}

A relational and critical approach to discourse analysis can be understood as one fully recognizing its relational or social nature. Such an approach to discourse analysis could be defined as a next step in the development of the understanding of contextuality. The development of linguistics over the last century can be interpreted as a process involving the gradual contextualization of its objects of study, which can also be seen as a process of gradually recognizing their relational nature. Step by step the contextual, relational character of such notions as the meaning of words, sentences, texts, and finally notions of discourse and context itself, has been recognized. Among the first stages of this process was recognition of the contextual nature of the meaning of particular words. In writing on the development of the notion of context, Charles Goodwin and Alessandro Duranti (Goodwin \& Duranti 1992) pointed to the seminal essay The Problem of Meaning in Primitive Languages by Bronisław Malinowski, who is often considered an ethnographic precursor of contemporary contextualism. As Goodwin and Duranti explain, Malinowski was probably the first to note 
that language is embedded within a situational context, and words only become comprehensible when the larger socio-cultural frameworks within which they are embedded are taken into account. Another important moment in the development of the contextual awareness of linguistic theory was Ludwig Wittgenstein's work, in which he famously declared that "the meaning of a word is its use in the language" (Wittgenstein 1953). Almost at the same time Yehoshua Bar-Hillel coined the notion of "indexical expressions" (Bar-Hillel 1954), marking an important step in the theoretical linkage between language and the context of its use. Another step in the development of linguistics was the recognition of contextuality in the function of words in a sentence (Sgall et al. 1986), which has been called the informative structure of sentences, or alternatively the topic-comment structure (Firbas 1992). Speech acts (Searle 1969) contextualized the rules for dividing text into units. This implied the gradual recognition of the contextual character of the criteria of textuality. The definition of text underwent gradual contextualization, which resulted in the emergence of the modern notion of discourse. Discourse, with its relational rules-including such structures as genres, registers, or styles—-started to be considered a context for particular texts. Soon, however, the arbitrariness of the way in which discourses were defined became more and more obvious. The next stage of this development was the questioning of the objectivity of the distinction between text and context. This was followed by a recognition of the social construction of context itself (e.g., Akman 2000). This process could be seen in terms of a gradual transition from "textual analysis" to "contextual analysis" and eventually to what could be called, after Jorge Ruiz Ruiz (2009), a "sociological interpretation." However, this recognition of the contextual or relational nature of context itself should not be considered the ultimate frontier of the process of deconstructing the social nature of the language world. What is, in fact, still not fully contextualized by discourse analysis is the discipline itself. In other words, while language use, discourse meaning, and other aspects of discourse games "outside" the realm of discourse analysis (as an academic field) are increasingly viewed as social and relational in their nature and involved in power relations, such a contextual perspective has not yet been systematically adapted to analysing the discourse of discourse analysis itself.

As I would like to propose in this text, the next step in the process of contextualizing its tools should be the recognition and systematic analysis of the relational character of discourse analysis itself. This would imply recognition of the relational but also arbitrary character of the distinction 
between discourse analysis on the one hand and the remaining social world on the other. The need for such an extension of contextualization is, however, not yet fully recognized and much of discourse analysis is still done in the old framework based on the assumption of the objective or neutral nature of the social science tools. Full recognition of the relational character of discourse analysis, and, in particular, of its tools, can been seen as a challenge that would imply the deconstruction of the still naturalized distinction between the discourse of discourse analysis itself and the remaining social world, including its discursive aspects. In other words, the distinction is still in place between social actions being the objects of discourse analysis' study and discourse analysis as an academic field not seen as part of the wider social world. It can be identified with the fundamental difference between a criticism of social relations, which are reflected in language forms, and a critical analysis of discourse analysis itself.

\section{/// Toward a New Relational Pragmatics}

The above-discussed gradual transition from non-contextual to contextual approaches may be related to the paradigmatic shift from semiotics to pragmatics (Levinson 1983). Its key aspect was the replacement of the criteria of truth by the criteria of efficacy/efficiency and the gradual redefinition of phenomena earlier considered to be purely linguistic acts of transmitting information into a wider category of social acts transforming states of the social world. This transition has been accompanied by the gradual replacement of ambitions to establish language norms by ambitions to study and reconstruct the existing, socially constructed norms of acceptability. The next stage of this process could also involve the recognition of these socially constructed norms and their reproduction, legitimized by the representatives of academia, as aspects of power relations. From the pragmatic perspective, norms of efficiency and of acceptability are both contextual. They can be seen as part of a larger set of social norms and relations of power in which a given social situation is embedded.

The development of a relational critical discourse analysis as opposed to what could be labelled the "public discourse analysis" of CDA, using Burawoy's term, can be seen as a reflection of a more general move forward in the process of the growing relational awareness of the social sciences (e.g., Emirbayer 1997 or Donati \& Archer 2015). In other words, this can be seen as an aspect of a new transition from the traditional pragmatics to a new, contextualized or relational pragmatics (Spencer-Oatey 2011). Such 
an approach can be imagined as a pragmatics recognizing, at least partly, its own immersion in the wider social world, particularly its embeddedness in wider relations of power relations. We can speak about a new pragmatics as a basis of discourse analysis and making such analysis aware of its own social, relational, and political nature. Such an approach would have a strong component of a critical sociology of discourse analysis. It would first of all adapt insights of what could be called Foucaultian discourse analysis (Diaz-Bone et al. 2007), which should at the same time be contextualized itself, bearing in mind its teleology largely focused on critique rather than description or explanation. As Gary Wickham and Gavin Kendall (2007) convincingly argue, the broadly understood Foucaultian discourse analysis in turning to critique inappropriately conflates description, explanation, and identification of causes with political criticisms. Wickham and Gavin (2007) suggest Max Weber's sociology as a possible empirical supplement to a mature discourse analysis. Reiner Keller's "sociology of knowledge approach to discourse" (Wissenssoziologische Diskursanalyse) in turn points to the importance of socially constituted actors in the social production and circulation of knowledge. Furthermore, it combines research questions related to the concept of "discourse" with the methodological toolbox of qualitative social research and addresses sociological interests, the analyses of social relations, and the politics of knowledge, as well as the discursive construction of reality as an empirical ("material") process (Keller 2005). In this context the "discourse-historical approach" proposed by Ruth Wodak, which attempts to integrate different approaches multi-methodologically and relies on a variety of empirical data and background information (Wodak 2001), could also be mentioned. In the sociological contextualization of discourse analysis, Pierre Bourdieu's apparatus seems equally helpful. Development of a sociologically informed critical perspective relying on the above-mentioned insights and schools could include analysis of the relations of discourse analysis (and its sub-fields) to other fields, in particular to what Bourdieu calls the "field of power" (Bourdieu \& Wacquant 1993). One direction of such an approach could be historical studies of institutional dependencies in the academic field of the study of languagein particular, discourse analysis - in the political and wider contexts of specific periods and countries. Among the most tangible aspects of such a dependency of discourse analysis on the logic of political power is the role it plays in the educational system, particularly in language instruction at all levels of schooling, which always includes larger or smaller amounts of linguistic theory. This is, of course, only one and probably the most vis- 
ible aspect of discourse analysis' direct role as a fundamental institution of a modern nation state, for which it provides both a legitimization system and the fundamental structure of the dominant culture. Other elements of that system are formal bodies aimed at the normalization of language, which are good examples of the role discourse analysts play in the implementation of such nation-state aims as cultural homogenization and political control over directions of language evolution. Their workings are usually backed by particular theories of language, which are also known as "language ideologies" (Gal 2009).

Critical discourse analysts may, of course, take the side of more or less marginalized groups, or at least try not to get directly involved in clearly politically oriented undertakings of hegemonic institutions. A relational engagement with such causes would require awareness of a person's own location within a wider social space. As Jan Blommaert (2005) argued, modern discourse analysts should be much more aware of their location in the hierarchically structured space of the world system - to use the term coined by Immanuel Wallerstein (Wallerstein 1974)—than most of them currently are. Their positioning near the central —or alternatively, peripheral-nodes of the global system may strongly impact the nature of their theories and interpretations and determine, above all else, their visibility and impact. A good example of these dependencies was provided by Elena Tarasheva, who scrutinized the publication patterns of Eastern European linguists (Tarasheva 2011). As she demonstrated, their articles rarely appeared in leading international journals. If this happens, Eastern Europeans mostly discuss case studies from their own countries using theoretical frameworks developed by their Western colleagues. Similar dependencies have been observed in other disciplines, such as geography (Timar 2004). Another aspect of discourse analysis' dependency on the field of power is the involvement of academics as experts in such structures as the media, the juridical system, and other public institutions. Such roles appear to be among the most extreme forms of the transformation of seemingly neutral academics into explicit members of the power establishment. Their scholarly status makes them useful to state institutions looking for additional legitimization of their decisions, which always have a more or less political nature. Using Burawoy's terms, such academics could be classified as partaking in forms of involvement in "policy discourse analysis" and "public discourse analysis." Blommaert quotes his own personal experience of serving as an expert for the Belgian migration authorities, for which he had been judging the "quality" of refugees' stories-in particular writ- 
ten texts (Blommaert 2005). As legal experts, discourse analysts are also involved in highly politicized trials all over the world. They have a crucial role, for example, in cases of "insult," "slander," or "hate-speech," given that their legitimizing function allows them to present sentences in "objective" academic terms. To justify their opinions they often refer to language and discourse theory. A good example of a systematic study of interaction between the academic field of linguistics and government is the work by Vincent Dubois (2014) reconstructing the role of French scholars in developing state language policies in the period 1960-1990. As he has demonstrated, representatives of academia tended to distance themselves from an overtly normative approach to language regulation, which may be seen as a form of emphasizing the autonomy of their academic sub-field. However, they engage much more actively in indirect forms of government intervention, such as campaigns for "language sensibility" (Dubois 2013: 5). These are among the most obvious forms of the involvement of academics studying language in the political field. Other less visible forms of such dependence are abundant and could be even more interesting as objects of study, given the much less evident nature of their politicization. In particular, a study could be made of how central research questions, theoretical notions and categories, and discourse analyses in given periods and regions of the world are linked to political interests of specific political actors and how they are inscribed within wider networks of relations of power. We can ask what their role is in the naturalization of these relations and hierarchies in line with other academic disciplines. A good example of such a context-induced transformation of research priorities in linguistics could be the switch of attention of discourse analysis from class categories (e.g., Labov 1966) to gender or racial categories (e.g., van Dijk 1993) as aspects of social inequalities reproduced and reinforced by language. An interesting contextual interpretation of the emergence of CDA as an intellectual response to the Thatcherite political project has been presented by Stef Slembrouck (2001). The development of institutional structures of discourse analysis could be similarly studied, taking into account the way state, political, and private actors are supporting the development of new research centres and their particular intellectual schools and individual researchers. These are, of course, only select examples of possible avenues for the development of this type of research. These questions can also be summarized as a call for the study of discourse analysis' contribution to the reproduction of different aspects of the doxa or "dominant ideology" (Bourdieu \& Boltanski 2008) in particular societies. I would like this arti- 
cle to be considered as a proposal for possible avenues for the development of a relational critical sociology of discourse analysis; critical sociology is defined here as following Loïc Wacquant's “questioning, in a continuous, active, and radical manner, both established forms of thought and established forms of collective life-_common sense' or doxa (including the doxa of the critical tradition) along with the social and political relations that obtain at a particular moment in a particular society" (Wacquant 2004: 97).

\section{/// Discourse Analysis in the Legitimization of Relations of Power}

What I propose is the development of a relational critical discourse analysis based on the idea of turning the tools of critical discourse analysis toward the analysis itself. As has been mentioned above, it can be argued that the discipline has so far been excluding itself in defining the social context of the phenomena it has been analysing. The new approach should involve identifying unequal access to the field of discourse analysis as an institutional field. We have to be aware that the discourse of discourse analysis can be seen as a social tool with a certain power to define, describe, and, in this way, change the social world. The ability to use it may be regulated by criteria that are either formal (e.g., academic degrees) or informal (recognition of competencies). In this context, hierarchies in the field of discourse analysis could be pointed out, particularly hierarchies of academic texts and of actors (authors, interpreters) enjoying different degrees of qualification that enable them to offer recognized interpretations of language behaviour. Bourdieu argued that "the autonomy of the 'purely' linguistic order, which is asserted by the privilege granted to the internal logic of language, at the expense of the social conditions and correlates of its social usage" is an illusion (Bourdieu \& Wacquant 1992). This suggests that discourse analysis itself asserts its own autonomy from the wider social world. At the same time, Bourdieu argued that

linguistic relations are always relations of symbolic power through which relations of force between the speakers and their respective groups are actualized in a transfigured form. Consequently, it is impossible to elucidate any act of communication within the compass of linguistic analysis alone. Even the simplest linguistic exchange brings into play a complex and ramifying web of historical power relations between the speaker, endowed with a specific social authority, and an audience, which recognizes this authority 
to varying degrees, as well as between the groups to which they respectively belong (Bourdieu \& Wacquant 1992: 142-3).

In adopting this view, we can also look at the relations between the academic sub-field of discourse analysis and the outside social world as power-relations games, in which discourse analysts cannot pretend to be neutral observers of social situations.

Thus I would suggest that, in contrast to traditional "discourse analysis," which can be seen as a good example of what Bourdieu called the "semiological vision of the world" (Bourdieu 2004), this new relational branch should focus on the social conditions of its own discourse production. Sociology, in particular its critical branch, has already studied several disciplines of the social sciences in more or less detail, including economics, political science and sociology itself; or at least it has reflected on their dependences on the field of power. In this context, the sociology of linguistics and, in particular, the sociology of discourse analysis, seems a relatively neglected direction of research. This does not mean that there have not been any previous contacts between sociology and linguistics. Among the first authors to propose such a critical sociological approach was James W. Marchand, who self-critically noted that "we linguists are not the free thinkers we wish to be and frequently present ourselves as. Our thought is 'socially' conditioned" (Marchand 1975). His work, however, had few suggestions regarding the specific methods of developing a sociology of linguistics. He barely pointed out the sociological mechanisms of the development of schools in linguistics-in particular, the crucial role of academic journals and conferences in molding the discipline. What I would propose, following in Marchand's steps, is the development of a relational sociology of discourse analysis understood as a reconstruction of its political functions and their evolution. It would include an analysis of relations between particular schools of discourse analysis within a wider field of linguistics and their relations to fields of power. These factors should be taken into account in all attempts at a relational analysis of the tools of discourse analysis. Here we perceive the rules of the function of language as rules of power; hence the study of language has to involve the study of power relations. We can note that the above proposition is based on the idea presented by Pierre Bourdieu: in particular, his view that the field of power is always dominant over all other fields, which can only be understood if their relation to the field of power is established. Moreover, as Bourdieu (Bourdieu \& Wacquant 1992) suggests, there is always a homology—some 
degree of similarity of structures — between any academic field and the field of power. This implies that any academic field may be divided into sections that have relations with particular parts of the field of power. At the same time, an academic field can be divided according to the criterion of generalized distance to the field of power, which produces a split between autonomous and heteronomous parts.

Adoption of such assumptions implies that any instances of discourse analysis can be interpreted as more or less directly related to divisions and stakes in the field of power and, in particular, involved in the fight over the very structure of the field of power. On the other hand, tensions in the field of power may become more or less directly reflected in all academic fields, including that of discourse analysis. The assumption of the superiority of the field of power implies a dependence of all other fields on the power relations the field of power generates and regulates. In effect, language rules codified-or at least reconstructed-by linguistics can be seen as having aspects of the political rules that regulate power relations in societies. The task of relational critical discourse analysis, in such a context, would be to identify the non-obvious political dimensions of the language rules codified by discourse analysts. A useful perspective is one proposed by Michiel Leezenberg, who recommends that we look at social contracts, with a focus on language rules as having a dominating and not cooperative character (Leezenberg 2002).

We can refer here to a basic opposition between two ways of modelling the social world. Following Martti Siisiäinen, we could distinguish between the universalistic paradigm of social integration and the antagonistic paradigm, which assumes the central role of conflict in social life (Siisiäinen 2003). The universalistic approach is best represented in discourse studies by Jurgen Habermas (Habermas 1984) with his "ideal speech situation" and claims of ideally cooperative speech exchange as a regulative ideal for all "communicative action." A good incarnation of this paradigm in sociology is Robert Putnam's (Putnam 1993) vision of "social capital" as a common resource, equally accessible to all members of a given community. Classic antagonistic paradigms were created by Carl Schmitt and Chantale Mouffe (Mouffe 2005). Pierre Bourdieu is also an influential representative; his theory excludes even the idea of a "genuine" consensus and universal values, the central function of which is to maintain such a paradigm in everyday practices. Such a conflict-based view of language usage, as Michiel Leezenberg argued, would be "one that systematically tries to account for the articulation of power relations in communication 
and signification, and abstracts away from questions of legitimacy. Such a conception would not imply a reduction of all communication to matters of power, but rather treat power as an irreducible aspect of all communication" (Leezenberg 2002: 906). Leezenberg also noted that "for Bourdieu, the efficacy of ritual speech acts cannot be separated from the existence of institutions conferring a legitimate authority on utterances. He argues that Austin and his followers mistakenly locate the power of words, in particular a speech act's illocutionary force, in the symbols used rather than in the language users conferring this authority on words" (Leezenberg 1999: 2). Leezenberg reminds us also that, according to Bourdieu, it is typical of symbolic power that it masks itself and is essentially mistaken for cooperation or mutual consent; it can only continue to function unproblematically under the condition of being misrecognized in this way (Leezenberg 1999). Looked at in the terms outlined above, the allegedly neutral status of discourse analysis as a "rational" apparatus for the analysis of social communication can be challenged. From such a perspective, the outcomes of discourse analysis can be seen as descriptions of legitimate and unchallenged forms of symbolic power.

\section{/// A Relational Critique of Selected Concepts of Discourse Analysis}

Besides looking at more or less direct institutional relations between discourse analysis and the field of power, we can also attempt to deconstruct specific basic tools employed by the discipline. These tools could also be seen as inscribed in the wider context of the power relations of a given society. It is through the social embeddedness of these categories that discourse analysis can be seen as an effective tool for reproducing and naturalizing the social order. One of the basic social functions of discourse analysis, in this perspective, could be defined as the hierarchization of texts. Intentionally or not, all acts of discourse analysis can be seen as having aspects of hierarchization, because any act of interpreting a text implies its direct or indirect assessment and its relative positioning in relation to other texts on different scales, which may include syntactic, stylistic, ideological, or other criteria of worth. This unavoidable normative outcome of any act of discourse analysis can be seen as an aspect of a more general social function of the social sciences, namely, the maintenance and legitimization of the social order. However, in some instances these mechanisms may serve to reinforce dominant social forces, while in others they may pertain only 
to some specific and relatively autonomous social fields, which are sometimes independent from or even opposed to the hierarchies of the core of a given society's field of power. Discourse analysis and its tools, as I would argue, should always be seen as part of a wider social system. The interpretation of a text, from this perspective, should be seen as an act of legitimate social appraisal. This function of discourse analysis is, however, difficult to identify in its traditional approaches. The naturalization of such social functions is largely based on framing interpretations through discourse analysis in terms of the assignment of specific characteristics to texts (or other language forms) and states of mind of individuals involved in their production or reception. The alternative approach, which I am proposing here, should see all characteristics of texts as socially produced, thus not as their innate features but as aspects of the wider social context in which they appear. Tools of discourse analysis should be seen, at the same time, as charged with normative mechanisms. We should be aware that they reflect a specific consensus reached in academic fields, but their origin stems from a confrontation over the definition and status of tools for the hierarchization of texts. Below I will try to offer a critical perspective on selected concepts of discourse analysis. First is the notion of context.

\section{Context}

Context, in its traditional understanding, which is still dominant in discourse analysis, is defined subjectively as those features of a social situation that speakers and/or interpreters consider relevant. Thus, for instance, Goodwin and Duranti (1992), referring to Ochs (1979), propose to distinguish the following: "dimensions of context" of linguistic behaviour, "setting," the "behavioural component," "language as context," and the "extra-situational context." Harris (1988) distinguishes seven dimensions of context: the world-knowledge dimension, the knowledge-of-language dimension, the authorial dimension, the generic dimension, the collective dimension, the specific dimension, and the textual dimension. As Bauman and Briggs point out, "all such definitions of context are overtly inclusive, there being no way to know when an adequate range of contextual factors has been encompassed. The seemingly simple task of describing 'the context' of a performance can accordingly become an infinite regress"' (Bauman \& Briggs 1990). Another form of such an approach to context is based on its cognitive models, as developed, for example, by Teun van Dijk (e.g., van Dijk 1999). It could be argued that this understanding of context 
appears to be highly arbitrary. In van Dijk's view, context is defined by components such as domain and situation, which in turn are divided into scenes and events. Events comprise such categories as participants, actions, cognition, etc. This manner of defining context can be called psychological, as its components are defined through the reconstruction of individual cognitive models of a situation. Context, here, is largely dependent on individual will and rests on individual cognitive structures. This approach can be seen as reflecting the paradigm that is still dominant in discourse analysis- one that Jacob Mey called a tendency to concentrate on "the language user as an autonomous agent, a kind of linguistic Robinson Crusoe, always reinventing the linguistic wheel" (Mey 1999: 598).

This paradigm can be contrasted to what can be called the sociological or relational approach, in which context is defined as an objectively existing social situation embedded in the wider web of power relations in a given society. Here context is independent from individual cognition and remains external in relation to the human brain. It is not seen as a feature of texts or as an internal mental state of an utterer, as such an approach naturalizes the power relations that produce the key structures of social contexts. We have to recognize that contexts may be influenced or coproduced by some specific discourses or texts as forms of social action, but they are above all independent of them. Contexts are overarching relational social constructs which can be operationalized in terms of Bourdieu's notion of field. As Bourdieu has suggested, any field enjoys some degree of autonomy, but none is fully autonomous, and to some degree all fields remain dependent on what he called the field of power. From this perspective, a relational critical discourse analysis must not restrict itself to the study of the linguistic world. It has to rely on a systematic sociological reconstruction of relations of social context in which both the texts studied and the discipline itself are involved. These contexts can be formally reconstructed as fields or networks (Bottero \& Crossley 2011), but they must be seen as socially constructed, relational and imbued with power relations which have to be exposed in a relational discourse analysis. Given that the autonomy of any social field is always restricted, no context can be reduced to a specific situation. What I would like to propose, therefore, is that a relational critical discourse analysis should recognize its dependence on other social sciences, in particular sociology, as such sciences study configurations of the non-linguistic aspects of social context. In such an approach, references to relations of power may not be simply perfunctory, as is the case in many instances of discourse analysis where the impor- 
tance of "power relations" is rhetorically recognized without a systematic reconstruction of specific social fields. A good example of such a study, which can be seen as an instance of what Blommaert calls a "reductive theory of power," is the analysis by Teun van Dijk, in particular his reference to specific debates in the House of Commons (e.g., van Dijk 2006). This study lacks any deeper insight into the configuration of the British field of power and the political scene, which should be seen as crucial contexts for the parliamentary speeches used as case studies by van Dijk. It seems that such a context is largely considered by the author to be self-evident, or inferable from the analysed texts themselves. The opposite approach I am advocating here could be seen as an attempt to take into account the consequences of recognizing the arbitrariness of the border between linguistic and non-linguistics aspects of the social world. This would imply recognition of the fact that the relatively narrow focus of the dominant schools of discourse analysis on linguistic phenomena results in a naturalization of the power relations within which they exist. It can, of course, be noted that this naturalization of hierarchies of power, which all academic disciplines are entangled in to some extent, may be one of the key reasons for the wider social relevance of discourse analysis. By decontextualizing acts of language use from their wider context, linguists are able to reinforce dominant social relations while at the same time naturalizing the political context of their emergence. Entirely rejecting this role would probably move discourse analysis to the margins of social interest. However, lack of awareness of it makes discourse analysts simple puppets in the hands of more powerful actors. In any case, a fully relational critical discourse analysis would be a discipline almost entirely integrated with other social sciences, preferably also in their relational incarnations. This could lead to questioning the need for the separate existence of linguistics, but some effort in this direction seems highly justified. The dialectical-relational approach to CDA proposed by Norman Fairclough (2009a) could be seen as one of the possible forms of implementing this way of thinking. In particular, Fairclough proposed that CDA should be integrated within the framework of what he calls transdisciplinary research, such as the school of "cultural political economy" (Jessop 2004).

\section{Criteria of Textuality}

Let me now discuss the implicit power-reproduction functions of some of the other tools of contemporary discourse analysis. A particu- 
larly inspiring case is provided by the well-known concept of standards of textuality developed by Robert de Beaugrande and Wolfgang Dressler (1981). Although their approach may be seen as no longer central to discourse analysis, most of the concepts popularized by de Beaugrande and Dressler remain important notions in contemporary text analysis. Their seven "standards of textuality" include "cohesion," "coherence," "intentionality," "acceptability," "informativity," "situationality," and "intertextuality." A good example of the continuing central role of de Beaugrande and Dressler's "standards of textuality" in contemporary discourse studies is a recent introduction to the discipline by Ruth Wodak (2008). To be sure, Wodak argues that the specific criteria should be assigned different importance and recognizes the contextual nature of "intentionality," "acceptability," "informativity," and "situationality," but overall she still presents them as fundamental concepts of discourse analysis. Let me remind the reader, that originally they were supposed to define which "communicative occurrences" could be classified as "communicative." De Beaugrande and Dressler considered texts that failed to meet their standards to be non-communicative "non-texts." As is typical for a traditional, individualistic approach, several of their standards of textuality pertain to psychological notions, characterizing inner states of the brain rather than social facts. Thus intentionality is defined as "concerning the text producer's attitude that the set of occurrences should constitute a cohesive and coherent text instrumental in fulfilling the producer's intentions" (de Beaugrande \& Dressler 1981: 7). Similarly, acceptability is also defined as the attitude (of the text receiver) "that the set of occurrences should constitute a cohesive and coherent text having some use or relevance for the receiver" (de Beaugrande \& Dressler 1981: 7). It was Herbert Blumer who pointed out that the notion of attitudes can be used as a tool to arbitrarily assign invented traits to individuals (Blumer 1969). The criteria of informativity, situationality, and intertextuality mentioned by de Beaugrande and Dressler do not refer to psychological characteristics; rather, they refer to texts and their contexts. Their practical assessment can also be, however, a highly subjective process. All in all, these standards are perfect examples of the mechanisms used in building text hierarchies. In addition, the entire list appears highly arbitrary. Whatever our criteria of textuality may be, assessment will always have an aspect of the exercise of power. After all, textuality appears to be a useful and academically legitimate tool that gives some texts more power than others. Thus de Beaugrande and Dressler's model and its later derivatives may be seen as a powerful social 
machine enabling a natural recognition of the privileged status of specific texts and a depreciation of others. "Standards of textuality" seem to be typical academic tools for the legitimization and delegitimization of any statements we would like to consider superior, inferior, or simply invalid. These seemingly formal and objective notions even allow those bestowed with academic competencies to delegitimize specific statements as cases of "non-text." What is simultaneously naturalized is the context of power relations that bestow legitimacy on the use of such academic tools. This is possible because the criteria of textuality are defined as characteristics of specific texts pertaining to states of minds of specific individuals. What is silenced is their implicit definitions and rules of application, which are governed by socially defined criteria and common-sense norms embedded in the dominant relations of power.

\section{Coherence}

A particularly interesting case of standards of textuality, which constitutes part of de Beaugrande and Dressler's system and several other approaches to discourse analysis, is that of coherence and cohesion. Many authors make a clear distinction between the two (coherence concerns the ways in which the components of the textual world are related, while cohesion concerns the ways in which the components of the surface text are linked). Here, however, I am not so interested in that distinction and will focus on a generalized notion of coherence that will pertain to its most typical uses. Michel Foucault challenged the objective nature of the notion of coherence in his seminal Archeology of Knowledge (Foucault 1972). Foucault rejected four hypotheses concerning the unifying principle of a discursive formation: reference to the same object, a common style in the production of statements, the constancy of the concepts, and reference to a common theme. As Foucault argued, discursive formations are not held together by any hidden rule or structure. Rather, they are held together by what he called "regularity in dispersion." Dispersion thus becomes the principle of unity, "insofar," as Ernesto Laclau and Chantal Mouffe phrase it, "as it is governed by rules of formation, by the complex conditions of existence of the dispersed statements" (Laclau \& Mouffe 1985). As Foucault argued, discursive formation is a configuration which in some contexts may be recognized as a whole. Thus the ability to declare a set of statements to be a coherent discursive formation becomes crucial and its political character seems obvious. Such an ability to identify coherent wholes-be they sen- 
tences, texts, or discourses - seems to be at the core of any theory dealing with the notion of coherence, just as with de Beaugrande and Dressler's concept of standards of textuality. In all these examples we can clearly see how linguists get involved in the power-laden game of hierarchizing statements, elements of which frame distinctions between "good" and "bad" or "valid" or "invalid" sentences, texts, or discourses. Discourse analysts may try to avoid making direct judgments in these matters; however, the theoretical notions they work with unavoidably make them produce, sometimes implicitly, such hierarchies. On many occasions such judgments are direct, as is the case with many statements about the coherence of specific texts. In fact the entire process of producing academic knowledge can be seen as a game based on assigning a different degree of coherence to texts competing for the status of most authoritative manifestos of a given discipline.

\section{Ideologization and Politicization}

There are several other notions commonly used in discourse analysis that can be deconstructed in a similar way. One major example is the role of genre. Genre analysis may be perceived as an area of confrontation between discourse analysis and other fields, in particular politics, the media, and other social sciences. Classification of particular statements in terms of genres often involves direct political controversies and is strongly linked to power relations (e.g., the distinction between news and opinion). This is, first of all, because such categorizations influence the status of particular statements and consequently their effectiveness. As Norman Fairclough has noted, "much actual political text and talk is hybrid with respect to genres, i.e., combines different genres together (...) How one defines and delimits politics is itself a political choice, and it determines how one delimits the genres of politics" (Fairclough 2009b: 293). This seems to be a good example of how tricky the assignment of "political" and "ideological" status to texts can appear. The identification of such traits of texts usually implies their depreciation, particularly in the academic field, because "politicization" and "ideologization" are ordinarily defined as incompatible with academic standards - given the assumption of the autonomous status of the field of science. What is, however, usually ignored in such cases is the arbitrary and usually political nature of the distinction between the fields of politics and the social sciences, or academia in general. It should be also emphasized that a "political" or "ideological" nature can not be assigned independently of the context in which such categorizations are possible. In 
other words, to be able to make at least some objective analysis of this kind we have to be aware of the social construction of the border between "political" and "academic" and its relational nature. We also have to be aware of the linkages of debates on an issue to specific configurations of the field of power in a given society. These linkages reflect the positions of the major actors in the field of power that are usually involved in arguments about specific definitions of the political.

The ideal distinction between "bad" politics and "good" academia is strongly linked to another important symbolic divide, namely that between reason and folly or emotionality and rationality. The power-relations aspects of these debates are of course well known, at least since Michel Foucault demonstrated the inner workings of the distinction between madness and rationality and its key role in the reproduction of power relations in contemporary societies. However, in discourse analysis, notions of emotion and emotionality continue to be used without reference to their social nature.

\section{Rhetorical Structures and Macrostructures}

The rhetorical structures assigned to texts can be shown to have a similar character. Their reconstruction always implies an assessment of the efficiency of texts, that is, their impact on power relations. Thus, argumentation analysis seems to be a highly normative branch of discourse analysis. It also shares the assumption about the cooperative nature of language interaction and marginalizes the dimension of power relations. A good example of such an approach is the so-called pragma-dialectical school of argumentation theory. Its fundamental assumptions include rules of "good discussion," which allow "fallacies" to be distinguished from "good" arguments (van Eemeren \& Grootendorst 1992). Luigi Pellizzoni (2001) has convincingly demonstrated how the "myth of the best argument," a notion commonly used in argumentation and deliberation studies, is based on the naturalization of power relations behind communicative interactions.

Another interesting case is the theory of macrostructures developed by Teun van Dijk (1980) and its applications. Reconstruction of macrostructures is by definition a subjective process, which refers to the supposed states of consciousness of readers and may imply changes in the status of an interpreted text. Identification of macrostructures is, at the same time, also conditioned by the social ability to make certain types of interpretations that imply a hierarchization of texts. Although the theory of macro- 
structures is strongly embedded in the language of cognitive psychology, it could be argued that the theory should rather be about the social logic of power relations, which conditions a person's ability to perform van Dijk's "macro-operations," including "generalization," "construction," and "deletion." Thus, for example, declaring part of a statement to be irrelevant or deleting or generalizing a larger part of a text in a particular way requires a particular social status, as the impact of such action may change power relations. All these operations produce-as the theory of macrostructures stipulates-representations of texts in the form of abstracts or the topics and themes assigned to them. These representations can in fact be seen as attempts to control texts and maintain their hierarchies. Specific forms of what van Dijk labelled generalization and construction (forms of summarizing and developing stories or exposing their hidden assumptions) are also procedures ruled by socially shared — though sometimes contestednorms which cannot be confined to mental operations. In other words, it can be argued that the macrostructures of texts are as much individual as they are social products.

\section{/// Conclusions}

As has been argued in this text, the academic analysis of language is still largely abstracted from the power relations underlying its own function. Discourse analysis will always be involved in games of categorizing texts and other language behaviours — as its analyses automatically imply the assignment of specific value to texts. Discourse analysis has to be seen as implicated in the social network of power relations. Any analysis of a text also implies an involvement in the construction and reproduction of hierarchies of texts, which are part of social hierarchies. Any textual analysis is itself an act of participation in the contest for the highest social status in the global text hierarchy and wider social world. A critical, relational sociology of linguistics can be seen, in this light, as an attempt to reconstruct the hidden aspects of the social and political work of linguists as well as the workings of critical sociology itself. This paper does not aspire to provide an objective and distanced analysis of either. As Pierre Bourdieu suggested, however, one way to reduce one's own subjectivity is through the systematic reconstruction of one's own place in the structure of the social relations in which we are involved - including the logic of social fields, their internal structures, and the dependencies between them. This seems to be one of the most fruitful avenues for the development of a relational critical 
discourse analysis, as it is understood in this text. It entails a proposition to analyse the location of all those involved in the academic study of language in their respective fields. It must also involve self-analysis of one's own social position, without which a person risks being fully captured by the dominant hierarchies of power, even if trying to challenge them. A good example of such a process was given by Michael Billig, who noted that $\mathrm{CDA}$ is gradually entering the mainstream of linguistic discourse, which makes the sense of "critical" in its name lose its original meaning (Billig 2000). This is another reason why I am calling here for a relational critical discourse analysis, which would have a much more self-critical focus on its own field. In particular, it would need to recognize the social and relational nature of its own tools and realize that their application can hardly be seen as an objective identification of the traits of specific texts and actors. This relational analysis should realize that these concepts are tools of power developed in a framework of specific social relations, whose primary function is the hierarchization of texts, which can be seen as part of a wider mechanism of the reproduction of social relations.

Acknowledgments:

Research presented in the paper has been financed by the National Science Center of Poland (NCN) within the framework of research project no. 2015/17/B/HS6/04161.

Bibliography:

/// Akman V. 2000. Rethinking Context as a Social Construct, "Journal of Pragmatics", vol. 32(6), pp. 743-759.

/// Bar-Hillel Y. 1954. Indexical Expressions, "Mind", vol. 63(251), pp. 359-379.

/// Bauman R., Briggs C.L. 1990. Poetics and Performance as Critical Perspectives on Language and Social Life, "Annual Review of Anthropology", vol. 19, pp. $59-88$.

/// Billig M. 2000. Towards a Critique of the Critical, "Discourse \& Society", vol. 11(3), pp. 291-292.

/// Blommaert J. 2005. Discourse: A Critical Introduction, Cambridge University Press. 
/// Blumer H. 1969. Symbolic Interaction: Perspective and Method, University of California Press.

/// Bourdieu P. 1983. The Field of Cultural Production, or: The Economic World Reversed, "Poetics", vol. 12(4-5), pp. 311-356.

/// Bourdieu P. 2004. Science of Science and Reflexivity, University of Chicago Press.

/// Bourdieu P., Boltanski L. 2008. La Production de l'idéologie dominante, Demopolis et Raisons d'Agir.

/// Bourdieu P., Wacquant L.J.D. 1992. An Invitation to Reflexive Sociology, University of Chicago Press.

/// Bourdieu P., Wacquant L.J.D. 1993. From Ruling Class to Field of Power: An Interview with Pierre Bourdieu on La Noblesse d'État, "Theory, Culture \& Society", vol. 10(3), pp. 19-44.

/// Bottero W., Crossley N. 2011. Worlds, Fields and Networks: Becker, Bourdien and the Structures of Social Relations, "Cultural Sociology", vol. 5(1), pp. 99-119.

/// Bucholtz M. 2001. Reflexivity and Critique in Discourse Analysis, "Critique of Anthropology", vol. 21(2), pp. 165-183.

/// Burawoy M. 2005. 2004 American Sociological Association Presidential Address: For Public Sociology, “The British Journal of Sociology”, vol. 56(2), pp. 259-194.

/// de Beaugrande R., Dressler W.U. 1981. Introduction to Text Linguistics, Longman.

/// Diaz-Bone R., Bührmann A.D., Gutiérrez Rodríguez E., Schneider W., Kendall G., Tirado F. 2007. The Field of Foucaultian Discourse Analysis: Structures, Developments and Perspectives, "Forum Qualitative Sozialforschung / Forum: Qualitative Social Research”, vol. 8(2).

/// Donati P., Archer M.S. 2015. The Relational Subject, Cambridge University Press.

/// Dubois V. 2014. Le rôle des linguistes dans les politiques de la langue française (1960-1990): éléments pour une analyse socio-politique, Dossiers d'HEL, SHESL, 2014, Linguistiques d'intervention. Des usages socio-politiques des savoirs sur le langage et les langues, https://halshs.archives-ouvertes.fr/halshs-01115127, pp. 1-6, accessed 10.10.2017. 
/// Emirbayer M. 1997. Manifesto for a Relational Sociology, "American Journal of Sociology", vol. 103(2), pp. 281-317.

/// Fairclough N. 2009a. A Dialectical-Relational Approach to Critical Discourse Analysis in Social Research, [in:] Methods of Critical Discourse Analysis, eds. R. Wodak, M. Meyer, Sage Publications, pp. 162-186.

/// Fairclough N. 2009b. Genres in Political Discourse, [in:] Concise Encyclopedia of Pragmatics, ed. J.L. Mey, Elsevier, pp. 293-298.

/// Firbas J. 1992. Functional Sentence Perspective in Written and Spoken Communication, Cambridge University Press.

/// Foucault M. 1972. The Archaeology of Knowledge, Tavistock Publications.

/// Gal S. 2009. Linguistic Anthropology, [in:] Concise Encyclopedia of Pragmatics, ed. J.L. Mey, Elsevier, pp. 519-533.

/// Goodwin C., Duranti A. 1992. Rethinking Context: An Introduction, [in:] Rethinking Context: Language As an Interactive Phenomenon, eds. C. Goodwin, A. Duranti, Cambridge University Press, pp. 1-42.

/// Habermas J. 1984. The Theory of Communicative Action, Beacon Press.

/// Harris W.V. 1988. Interpretive Acts: In Search of Meaning, Clarendon Press.

/// Jessop B. 2004. Critical Semiotic Analysis and Cultural Political Economy, "Critical Discourse Studies", vol. 1(2), pp. 159-174.

/// Jones P.E. 2007. Why There Is No Such Thing As "Critical Discourse Analysis", "Language \& Communication", vol. 27(4), pp. 337-368.

/// Keller R. 2005. Analysing Discourse: An Approach from the Sociology of Knowledge, "Forum Qualitative Sozialforschung / Forum: Qualitative Social Research", vol. 6.

/// Labov W. 1966. The Social Stratification of English in New York City, Center for Applied Linguistics.

/// Laclau E., Mouffe C. 1985. Hegemony and Socialist Strategy: Towards a Radical Democratic Politics, Verso.

/// Leezenberg M. 1999. Symbolic Power, Illocutionary Force, and Impoliteness: A Critical Look at the Foundations of Speech Act Theory, Symposium Amstelogue. 
/// Leezenberg M. 2002. Power in Communication: Implications for the Semantics-Pragmatics Interface, "Journal of Pragmatics", vol. 34(7), pp. 893-908.

/// Levinson S.C. 1983. Pragmatics, Cambridge University Press.

/// Marchand J.W. 1975. Towards a Sociology of Linguistics, Conference Paper.

/// Mey J. 1999. When Voices Clash: A Study in Literary Pragmatics, Mouton de Gruyter.

/// Mouffe C. 2005. On the Political, Routledge.

/// Ochs E. 1979. Introduction: What Child Language Can Contribute to Pragmatics, [in:] Developmental Pragmatics, eds. E. Ochs, B.B. Schieffelin, Academic Press, pp. 1-17.

/// Pellizzoni L. 2001. The Myth of the Best Argument: Power, Deliberation and Reason, "The British Journal of Sociology", vol. 52(1), pp. 59-86.

/// Putnam R.D. 1993. Making Democracy Work: Civic Traditions in Modern Italy, Princeton University Press.

/// Ruiz Ruiz J. 2009. Sociological Discourse Analysis: Methods and Logic, "Forum Qualitative Sozialforschung / Forum: Qualitative Social Research", vol. 10.

/// Searle J.R. 1969. Speech Acts: An Essay in the Philosophy of Language, Cambridge University Press.

/// Sgall P., Hajičová E., Panevová J. 1986. The Meaning of the Sentence in its Semantic and Pragmatic Aspects, Kluwer.

/// Siisiäinen M. 2003. Two Concepts of Social Capital: Bourdieu vs. Putnam, "International Journal of Contemporary Sociology", vol. 40(2), pp. 183-204.

/// Silverstein M., Urban G. 1996. Natural Histories of Discourse, University of Chicago Press.

/// Slembrouck S. 2001. Explanation, Interpretation and Critique in the Analysis of Discourse, "Critique of Anthropology", vol. 21(1), pp. 33-57.

/// Spencer-Oatey H. 2011. Conceptualising 'the Relational' in Pragmatics: Insights from Metapragmatic Emotion and (Im)politeness Comments, "Journal of Pragmatics", vol. 43(14), pp. 3565-3578.

/// Timar J. 2004. More Than 'Anglo-American,' It Is 'Western': Hegemony in Geography from a Hungarian Perspective, "Geoforum”, vol. 35(5), pp. 533-538. 
/// van Eemeren F.H., Grootendorst R. 1992. Argumentation, Communication, and Fallacies: A Pragma-Dialectical Perspective, Lawrence Erlbaum Associates.

/// van Dijk T.A. 1980. Macrostructures: An Interdisciplinary Study of Global Structures in Discourse, Interaction, and Cognition, Lawrence Erlbaum Associates.

/// van Dijk T.A. 1993. Elite Discourse and Racism, Sage Publications.

/// van Dijk T.A. 1999. Context Models in Discourse Processing, [in:] The Construction of Mental Representations During Reading, eds. H. van Oostendorp, S.R. Goldman, Lawrence Erlbaum Associates, pp. 71-98.

/// van Dijk T.A. 2001. Critical Discourse Analysis, [in:] Handbook of Discourse Analysis, eds. D. Tannen, D. Schiffrin, H.E. Hamilton, Blackwell, pp. 352371.

/// van Dijk T.A. 2006. Discourse and Manipulation, "Discourse \& Society", vol. 17(2), pp. 359-383.

/// van Leeuwen T. 2009. Critical Discourse Analysis, [in:] Concise Encyclopedia of Pragmatics, ed. J.L. Mey, Elsevier, pp. 166-169.

/// Wacquant L.J.D. 2004. Critical Thought as Solvent of Doxa, "Constellations", vol. 11(1), pp. 97-101.

/// Wallerstein I.M. 1974. The Modern World-System, Academic Press.

/// Wickham G., Kendall G. 2007. Critical Discourse Analysis, Description, Explanation, Causes: Foucault's Inspiration Versus Weber's Perspiration, "Forum Qualitative Sozialforschung / Forum: Qualitative Social Research”, vol. 8.

/// Wodak R. 2001. The Discourse-Historical Approach, [in:] Methods of Critical Discourse Analysis, eds. R.Wodak, M. Meyer, Sage Publications, pp. 63-95.

/// Wodak R. 2008. Introduction: Discourse Studies-Important Concepts and Terms, [in:] Qualitative Discourse Analysis in the Social Sciences, eds. R. Wodak, M. Krzyżanowski, Palgrave Macmillan, pp. 1-29.

\section{/// Abstract}

This paper proposes a relational and critical sociological perspective on discourse analysis, in particular on so-called "Critical Discourse Analysis" (CDA). The main argument of this paper is that CDA has not yet been able to turn its critical perspective towards its own field. Meanwhile, 
neither CDA nor other schools of discourse analysis can still pretend not to be integral parts of the system legitimizing social hierarchies in modern societies. The paper argues that discourse analysis can be seen as highly dependent on power relations, both because of its institutional positioning and because of its restricted reflexivity. A call for the development of a critical sociology of discourse analysis based on a relational approach is therefore presented. Its draft programme is largely based on inspiration from the sociology of knowledge, in particular from "the sociology of sociology" of Pierre Bourdieu.

Keywords:

critical theory, discourse analysis, pragmatics, sociology of linguistics

/// Tomasz Zarycki-associate professor and director of the Robert Zajonc Institute for Social Studies at the University of Warsaw, Poland. He holds a habilitation degree in sociology from the Institute of Philosophy and Sociology of the Polish Academy of Sciences in Warsaw. His research focuses on the sociology of politics, sociology of culture, sociology of knowledge, critical sociology, and discourse analysis, particularly in regard to Polish and Eastern European societies. His latest book in English is Ideologies of Eastness in Central and Eastern Europe (2014). His articles have appeared in journals such as "Communist and Post-Communist Studies," "East European Politics and Societies," "Europe-Asia Studies," "GeoForum," "Journal of Communist Studies and Transition Politics," "Kultura i Społeczeństwo," "Russian Education \& Society," "Theory and Society," and several others.

E-mail: t.zarycki@uw.edu.pl 